\title{
Regional Sustainable Development in France: Assessing the Environmental Implications
}

\author{
F. Bertrand and C. Larrue \\ University of Tours
}

Fichier auteur

\begin{abstract}
This article considers the environmental dimension of regional sustainable development in France. The first part evaluates the position of the environment in regional sustainable development policies using two levels of analysis. Firstly, it examines the stated objectives for regional sustainable development that relate to a balanced integration of the environmental dimension in relation to the economic and social dimensions. Second, it demonstrates how efforts to implement regional sustainable development (RSD) invariably lead to domination by environmental factors, as a consequence of well-established environmental policies. Thereafter, a critical analysis of this outcome is presented, illustrating how the disparity between what is said and done has produced an ambiguous notion of sustainable development (SD), and how different actors have adopted strongly opposing views. This confusion has created resistance by environmental actors who perceive sustainable development as potentially diluting environmental demands. The article concludes by discussing the possible future role of the environment within regional sustainable development.
\end{abstract}

Keywords: French regional planning; regional sustainable development; evaluation process; environmental assessment

\section{Introduction}

In France, regional development implementation is the responsibility of institutionalised regional authorities. The idea, and then reality, of the région were established over a 30year period (1956-1986) with a slow transformation from an administrative vision of the region to a regional public body, and then the gradual emergence of an identifiable regional power. The region is thus the most recent territorial division, created in 1982 as 
an autonomous decentralised body (see Figure 1). Since then, this authority has played an increasingly active role, especially in issues of regional economic development.

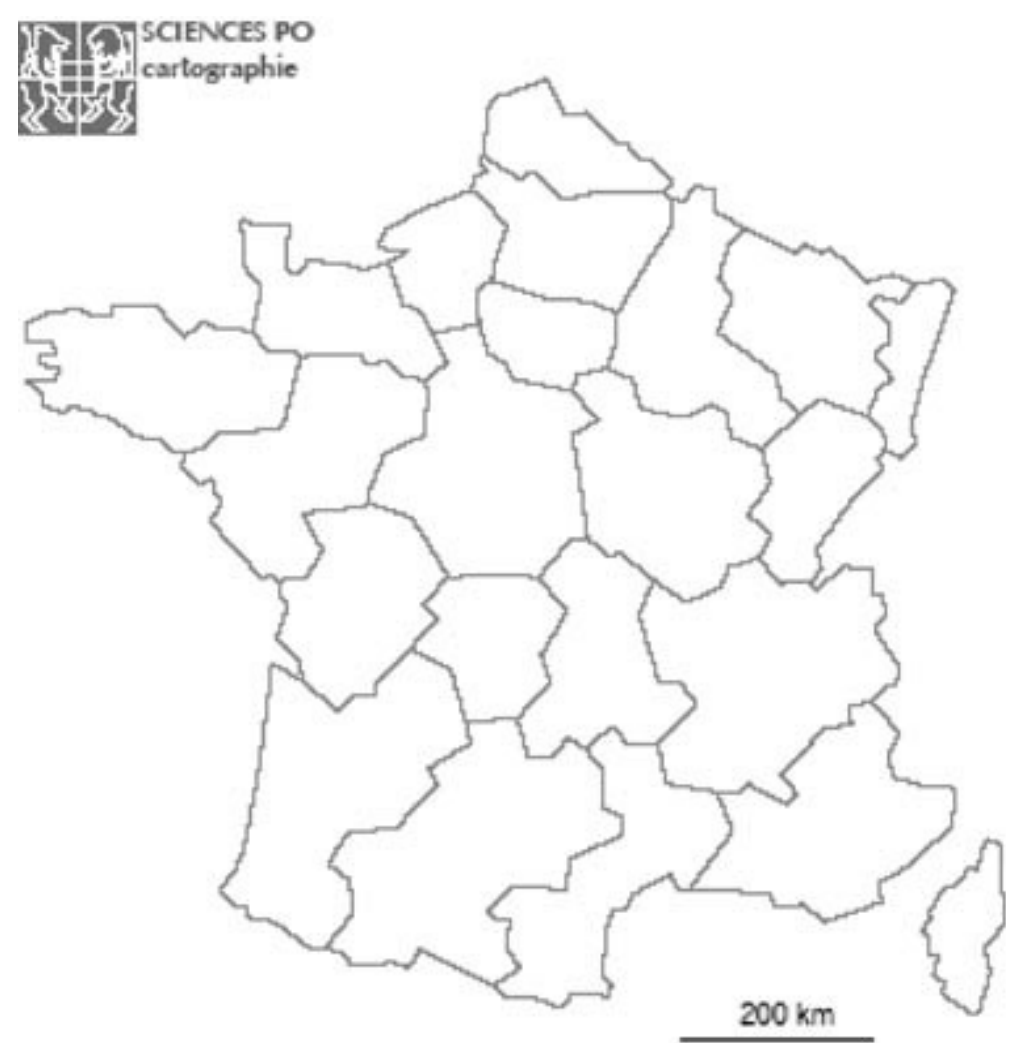

Figure 1. Map of the 26 French regions

Regional policies were initially based on planning processes (Lagugie et al., 1985; Laborie et al., 1985), but these were reformed in 1982 as part of the decentralisation process. At that point, a new legal framework imposed a process of partnership between state administration and regional governments, and to a lesser extent with European and local institutions. This partnership is based on a formally contracted process between the state and the regions for joint actions within a 7-year plan ${ }^{1}$, commonly known as the

\footnotetext{
${ }^{1}$ Prior to 2000 , the plans encompassed a 5-year timescale.
} 
"Contrats de Plan Etat Région" (CPER) (state-region planning contract) ${ }^{2}$. While the state agreed to share planning and development powers with the régions, it remains very active in these systems and procedures through its departments, organising a degree of tutelage and interdependence between the regional and national levels, particularly through financial instruments.

Since the beginning of the 1990s, the issue of sustainable development has steadily developed a stronger profile within the French administrative-political system, with initiatives undertaken by local and regional authorities and by national government (Bertrand, Larrue \& Héland, 2003: 11-18). More precisely, sustainable development has been introduced into the legal framework, especially in the domain of regional development, with the adoption in 1999 of the Law for Regional and Sustainable Development (Loi d'Orientation pour l'Aménagement et le Développement Durable du Territoire). At the same time, between 1998 and 2001, a new position was created, that of minister for regional development and the environment (Ministère de l'Aménagement du Territoire et de l'Environnement - MATE).

The law for Regional and Sustainable Development, which is known as the "Voynet" law, attempts to provide common references for regional action. In Article 1, it states that: "The national policy for regional and sustainable development allows a balanced development of the whole national territory, social progress, economic efficiency and protection of the environment". According to this Law, action programmes set up by

\footnotetext{
2 The current Planning Contracts between the State and the French regions relate to the period 20002006.
} 
local governments in large urban areas (agglomérations) as well as in rural areas (pays) must follow the principles of Agenda 21.

As this framework provides new opportunities to integrate SD into regional development policies, it is interesting to examine how the law has been implemented. Accordingly, the main theme addressed in this paper is how these new objectives for regional development have impacted upon pre-existing environmental policies: to what extent does the introduction of SD strengthen or weaken the environmental features of regional policy?

The first part of the article focuses on evaluating the status of the environmental dimension in regional sustainable development policies. For this task, two levels of analysis are proposed. Firstly, we review the stated objectives for regional sustainable development that relate to a balanced integration of the environmental dimension alongside the economic and social dimensions. Secondly, we demonstrate how efforts to implement regional sustainable development have led to dominance by the environmental dimension. In our opinion, this outcome is explained by well-established environmental policies rather than by the recent (and precarious) institutionalisation of sustainable development. The second part of the paper presents a critical analysis of this situation. The disparity between what is said and done has produced an ambiguous notion of sustainable development, used in different ways by actors with strongly opposing views, and this dichotomy has created resistance from environmental actors who see sustainable development as potentially diluting environmental demands. The 
article concludes with a discussion of the possible future role of the environment within regional sustainable development.

\section{1 - Regional sustainable development: strengthening the environment}

The national approach to environment underpins regional sustainable development in France. In character, the environmental dimensions of public policies in France are highly protective, conservationist (preservation of biodiversity, safeguarding breeding conditions, minimising waste, etc.) and negative (focusing on damage, impact and risks to the environment, etc.). The new environmental policy was developed around the idea of the quality of the environment in which we live (preventing water and air pollution, controlling waste, improving living conditions, protecting nature). In addition, people are much more aware of local and perceptible damage to the environment such as illegal dumping or water pollution, than of diffuse risks such as those associated with nuclear energy or transport of hazardous materials (Dupoirier, 1999).

\section{a. Promotion of a balanced approach}

Initiatives linked to sustainable development in France have been relatively slow to start and limited in scope, taking various forms but always remaining close to the environmental sector. However, regulatory advances have recently been made in the domain of regional development, without linking sustainable development to explicit and defined legal concepts. In particular, regional development policy reform has provided an opportunity to demonstrate an attachment to the objective of sustainable development without giving it a precise definition or a real legal value (Cans, 2003). 
For example, the law states that "within a coherent and integrated Europe, the national policy for regional sustainable development allows balanced development across the whole national territory, combining social progress, economic efficiency and environmental protection. It provides favourable conditions for job creation and national wealth... while preserving for future generations the available resources as well as the quality and diversity of the natural environment." 3 Prime Minister Jospin was equally elliptical in his circular concerning the State-Region Contract Plans for 2000-2006, in which he stated that "We need a new type of development which is longterm and concerned with both job creation and new activities and their sustainability i.e. that is compatible with economic efficiency, social justice and the preservation of our environment."4

Thus, regional policy texts have had to pursue a balanced objective for sustainable development with regard to the environment, the economy and social affairs. However, these aspirations were not accompanied by technical strategies, practical details or clear legal requirements, and those responsible for their implementation were left without guidance. The environment emerged from this discourse as the most visible and identifiable issue, and accordingly it has been the main beneficiary of the initiatives that have been launched.

\section{$\underline{\text { b. Regional initiatives }}$}

The situation of the French regions in relation to sustainable development varies considerably from one region to another. ${ }^{5}$ The chief characteristics of sustainable

\footnotetext{
${ }^{3}$ Extracts from the Directive Law for Land Management and Sustainable Development (June 1999)

${ }^{4}$ Extract from the Prime Minister's circular to the regional Prefects of 31 July 1998 concerning the forthcoming CPERs and the principles relating to their design.

${ }^{5}$ There are currently 26 French Regions, including Overseas Departments.
} 
development initiatives undertaken by the regions are diversity and heterogeneity: diversity in nature and in the areas explored by the initiatives, and heterogeneity in the levels of involvement and investment.

\section{The diversity of regional motivation}

At the request of the French Ministry for Regional Development and Environment, a report was prepared on sustainable development in six regions (Holec, 2001). ${ }^{6}$ This document provides an overview of the situation and illustrates the differentiated motivations for regional sustainable development. A related study identifies the stages on the path to sustainable development within the regions (Bertrand, 2004: 420-427) from which three categories may be drawn. Most French regions fall into the first two descriptions, with only a minority in the third:

- Regions that have not yet initiated specific procedures, with degrees of publicity varying from no reference to sustainable development to a simple declaration of intent;

- $\quad$ Regions that are considering the issue and ways of approaching it in practical terms, where there is evident will and political support, but with procedures still in an embryonic stage; and

- Pioneering regions, already well ahead in the process of incorporating sustainability into their policies and which have been involved in discussions on the issue for several years. These authorities show an interest in the issue, and they have taken a pro-active approach, for different reasons:

i) Physical - difficult local circumstances, with environmental problems requiring immediate consideration. The new perspective offered by sustainable 
development as a strategic response appears even clearer when the problems encountered in the regions are linked to serious crises that cannot be solved by the usual means. It could involve local environmental crises (e.g. transport, greenhouse effect and air pollution in the Paris area, or water resource management in Brittany), social or economic problems (e.g. out-migration from regions), or all three dimensions (e.g. regions such as Nord-Pas-de-Calais, currently pursuing diversification).

ii) Political - strong support for the Green Party, with elected representatives in the regional councils taking up this issue (as in Ile de France, for example, and particularly in Nord-Pas-de-Calais, the first French region to have had a "green" President - Marie-Christine Blandin from 1992 to 1998).

iii) Regional marketing - where communication about sustainable development acts effectively as a label of quality for the region.

Each of these regions is in advance of the majority because of a particular attribute physical, political or communication-related - and they can become interconnected: "It can be observed that in certain regions, isolated initiatives predominate, while in others the players have started to organise themselves and to work together to promote and implement sustainable development. How far they have advanced varies from one region to another depending on the political support given to the process" (Holec, 2001: 50).

\section{Results of national analysis and case studies}

From the cases examined by Bertrand (2004), differentiated results emerge in practice. At the regional administrative level, sustainable development raises the awareness of

\footnotetext{
6 Prepared by the 4D Association - Dossiers et Débats pour le Développement Durable
} 
technical staff to cross-sectoral approaches. However, public participation is still minimal, at best amounting to information provision, and there is no real conversion of discussion into concrete actions regarding citizenship and governance.

With regard to the instances of regional planning on a contractual basis, the introduction of sustainable development had the following effects:

- strengthening the environment (legitimacy and means), the emergence of new SD-related standards such as the HQE (High Environmental Quality Standard $)^{7}$, the promotion of environmental management systems, and informing other sectors about environmental concerns;

- the emergence of new criteria for public action, such as respecting equal opportunities for men and women;

- peripheral influence on major sectors of intervention (transport, agriculture, etc.), with the exception of State Education (the largest state department in terms of workforce) where no impact was discernible; and

- for less institutionally structured concerns - social economy, decentralized co-operation or fair trade - sustainable development principles were pursued without significant direct assistance.

\section{Environmental evaluation as a driving force for the assessment of sustainable development}

Even on the basis of the relatively standardized analytical framework of the regional planning contracts ${ }^{8}$, whose higher levels specifically encourage the Regions to carry out sustainable development evaluation, regional experience varies widely in form and

\footnotetext{
[www.association4d.org]

${ }^{7}$ http://www.assohqe.org/

8 This includes CPER and European regional policies relating to the Structural Funds (formalised and finalised as Single Programming Documents - SPDs).
} 
extent. This is a period of exploration, experimentation and dissemination of new practices. In this context, the involvement of several political and/or administrative actors as leaders seems to be a determining factor. In the same way, effective linkages and co-ordination functions rely heavily on the role of the experts involved in the process.

Analysis of the progress of the CPER 2000-2006 environmental evaluation processes shows that environmental policy evaluation is applied almost nationwide and evaluating the environmental impact of other actions is becoming widespread. Nevertheless, broader and more ambitious assessment approaches towards sustainability are more recent and few in number. Observations based on actions planned by the Regions show that while there are many environmental policy evaluation procedures and some environmental impact assessments of regional policy, attempts to introduce evaluations in other areas are rare, particularly in the social domain.

Nord-Pas-de-Calais represents one of the most advanced regions in terms of RSD, where the evaluation system set up to manage the CPER has been studied using a grid (cf. Table 1) to appraise the coherence of regional policies with sustainable development.

\footnotetext{
Meeting human needs

1. Improving the quality of services and facilities

2. Making services and facilities available for all departments

3. Personal responsibility and autonomy

4. Increasing community spirit within the target population

5. Personal qualifications and social integration

6. Diversification of socio-cultural activities

7. Consideration of spatial equity

8. Consideration of long-term needs

9. Fight against poverty

10. Consideration of social costs
}

Table 1. Matrix for appraising the coherency of regional policies with sustainable development Regional Council of Nord-Pas-de-Calais. 
Management of the environment

11. Controlling non-renewable resources

12. Limiting pollution and nuisances

13. Enhancing natural wealth and biodiversity

14. Controlling urban spread

15. Developing clean and simple technology, and/or quality-controlled products

16. Observing and anticipating events

17. Accounting for environmental costs

Economic development

18. Improving economic production and better distribution of capital gains

19. Strengthening employment assets

20. Developing "community business"

21. Instigating and developing alternative economy initiatives

22. Diversifying economic activities

23. Looking for better control of expenses

Participation/governance

24. Citizens' involvement, and recognition of their contribution

25. Setting up diagnostic procedures prior to action

26. Experience-sharing between actors and pooling of knowledge

27. Matching means with actors; non-competitive actions

28. Qualifications of partners and long-lasting partnerships

29. Recognizing all skills within the region (transversality) during programming,

implementation and monitoring phases

30. Implementing the evaluation procedure and taking account of the results

Source: DPE, Regional Council Nord-Pas-de-Calais, April 2001.

The results of the analysis using this matrix show that about a third of the sustainable development indicators of the CPER relate to management of the environment, a quarter of the sustainable development indicators cover meeting human requirements, while economic development and parity account for approximately a sixth each. A very small share of indicators is devoted to measuring advances in the field of participation and governance. In short, the environment is over-represented, and participation and governance are minimally represented.

It is also important to emphasise that the evaluation procedures in the Regions, even the most ambitious, experience difficulty in tackling central but sensitive questions on issues such as regionalised sustainable development, inter-regional solidarity (effects and interactions of the regional territory with other regions) and inter-generational solidarity. The only indicators and criteria covering these areas are those linked to longterm management and to the consequences of regional actions on the greenhouse effect. 
The relationship of evaluation systems with the rest of the world (neighbouring regions, extending gradually to the whole planet) is a new aspect for consideration in regional policies, arising directly from the spatial realisation of sustainable development. ${ }^{9}$ Significantly, it is also one of the main points lacking in the evaluation systems of regional policies.

Just as the wider territorial and temporal aspects are difficult to manage with the conventional tools of public policy management, the links between the economic, social and environmental aspects are weak. Integration seems most advanced at the point where environment and economy interact, particularly in terms of jobs linked to the environment, environmental management, the use of renewable energy in companies, pollution-control industries, etc.

Assessment of sustainable development is thus valuable as a learning tool from two points of view: on the one hand, by making regional policy managers aware of and responsible for sustainable development and its implications for programmes; and on the other hand, by providing all the institutions in the regional system with assessments from departments specialised in forecasting and strategic planning.

To summarise, there have been advances in the role of the environment in evaluation operations in recent years, but the objective of cross-sectorality between the different aspects of sustainable development is clearly more difficult to achieve. The extra-

\footnotetext{
${ }^{9}$ Compare in particular Zuindeau, 2000.
} 
territorial aspect, which is an important addition to the regionalisation of sustainable development (Zuindeau 2000), is barely in evidence. The environmental dimension of RSD varies according to how "the environment" is understood and recognized, dependent in particular on regional strategic issues and the temporal and spatial perspectives selected. In each region, "restorative" and "innovative" concepts are found in different proportions, varying with the state of the environment and the actors involved - a form of "survive together" skills-sharing approach occurs, particularly between minimal functions, when the State has main responsibility; and a "live together" attitude emerges when the regional authorities are in charge (Theys, 2002).

A gap can be identified between the regional policy objectives of balancing the social, environmental and economic aspects of development, and the reality observed in the regions where the environmental dimension has become a key factor in implementing RSD. Nevertheless, such "environmentalisation" of SD may also result in "economisation" of the environment, i. e. there is a risk that the environment will be absorbed within sustainable development and lose influence.

\section{2- Towards a dilution of the environment in Sustainable Development?}

At a practical level, the uncertainties between environment and SD may produce caution on the part of environmental actors who are concerned that the SD momentum will subsume environmental issues. These individuals may prefer to restrict their involvement, rather than gamble on SD with its potentially large but uncertain gains. This mistrust of SD reflects suspicions that industrialists are exploiting the concept to secure market deregulation. Accordingly, sustainable development may divide as much 
as it unites within the environmental movement, as shown in the title of the France Nature Environnement conference in 2002: "Sustainable Development: Hope or Imposture?" Greenpeace adopted an even more radical stance and banned the term, deeming it overused ${ }^{10}$.

Although environmentalists were more involved than other professions in drawing up, disseminating and popularising the concept of SD, they have become disillusioned about its effectiveness. For instance, as major companies such as EDF (which has a monopoly on supplying electricity in France, mainly nuclear) began using SD as a marketing tool, a large number of environmentalists radically rejected the SD concept. This group sought to put forward an alternative for countries in the North around the concept of "downscaling" (décroissance), which is often linked with the adjectives "sustainable" or "convivial" ", reminiscent of the work of Ivan Illitch". This movement is in keeping with the work of the economist Georgescu Roegen ${ }^{13}$ (who incorporated thermodynamic principles, particularly the principle of entropy, into economics, creating the concept of bioeconomics) (Roegen, 1971). French economists working on North-South development issues have also developed these ideas (Partant, 1982; Latouche, $1991 \&$ 1999). It is above all the concept of development that lies at the heart of their criticism, as illustrated in the work of Rist (Rist, 1996).

\footnotetext{
${ }^{10}$ Cf. P. Piro, «Un concept à géométrie variable », Politis n711-712, July-August 2002, p.27

${ }^{11}$ For a current outline of this idea, see for example the article by Hervé Kemp "Sauver le monde par la "décroissance soutenable" !" in Le Monde, 2 February 2002 or visit the web site www.decroissance.org/

12 These ideas are experiencing renewed interest in France, as shown by an international conference on post-development held at the Unesco Palace in Paris from 28 February to 3 March 2002, called "Défaire le développement, refaire le monde"

${ }^{13}$ As shown by the recent congress held in Lyon in September 2003, entitled "La décroissance soutenable

- Bioéconomie, écologie et simplicité volontaire".
} 
The reality of SD faced with analysis of French law: a political principle with no legal value

There is some basis for the persistent doubts and mistrust regarding risks to the environment from sustainable development. Investigations into legal status show that while there is no legal concept of sustainable development, it does fulfil political functions that could weaken and obscure the rights of the environment. Within this framework, two distinct functions are those of substitution (of the environment) and legitimisation (of actions outside the domain of the environment) (Cans, 2003).

- $\quad$ Substitution: sustainable development is gradually replacing the terms "protection, preservation, conservation". "This can easily be seen in the designations now given systematically to these policies, and even to the institutions responsible for implementing them" (Cans 2003: 216). The official replacement of the term "protection of the environment" by "sustainable development" highlights the word "development" and obscures that of "protection", which has consequences "at least on the underlying ethics". As a "terminological contrivance", sustainable development takes on a role of clouding the issue. Trivialising the word "sustainable" by using it to qualify all sorts of sectoral policies could thus lead to "obscuring legal and real obligations", which could ultimately lead to "anti-law" situations. ${ }^{14}$

- Legitimisation: The increase in the use of the term "sustainable development" for all purposes serves above all to legitimise certain public or private activities whose main aims are ostensibly not that of protecting the environment (agriculture, forestry, rail transport, banks, audit offices, etc.). Here, sustainable development does not replace anything, as protecting the environment has never been central to their concerns. "This legitimisation, the "environmentalisation" of the 
language used in company reports for example, constitutes at the very least a "recycling" and often an imposture. In its legitimisation role, sustainable development is reduced to an incantatory slogan" (Cans, 2003: 218). A paper in Antipode on sustainability as legitimating discourse in the case of forestry and mining sectors underlines the same issue (Bridge \& McManus, 2000).

These two functions carry a serious risk of obfuscation, hindering and weakening environmental law by emphasising the "developmentist" view, to the detriment of the "protectionist" perspective. This "appearance of law" provided by SD then runs the risk of becoming only a "law of appearances"15. Within the context of French law, sustainable development thus emphasises human-centred development concerns to the detriment of concerns for non-human and fundamentally less self-interested environmental protection, while paradoxically it also prevents systemic approaches and encourages deregulation (Cans, 2003): "From confronting a legal non-existence with powerful political messages (...) can arise the impression of a slogan which is potentially dangerous for the future of the environment and for maintaining an environmental protection policy. As defined in internal law, sustainable development is in no way synonymous with environmental protection, nor with preserving resources and natural wealth. The underlying priority is that of development (notably economic) and it contains, in itself and through its usage, perverse effects (...) It hinders the aim of non-human environmental protection and conservation. It assumes a purely humancentred approach to the environment. It excludes any systemic approach, and ultimately risks serving as a pretext for deregulation.” (Cans, 2003 : 211).

\footnotetext{
${ }^{14}$ Situations in which actions presented as exemplary with regard to SD, without fulfilling the inherent statutory requirements of their activities, use this image so as not to meet all their legal obligations.

${ }^{15}$ The title of the article that this work is based on reflects this idea: "Sustainable development in national law: the appearance of law and the law of appearances" (Cans, 2003)
} 
This analysis, based on an implementation of SD at a national level, also applies to the regional level.

\section{The economization of environmental policies}

Sustainable development is thus a process that the design of all current policies must follow or incorporate. Perhaps alongside the "environmentalisation" of language and recycling of the environment into economic parlance, there should be a similar "economisation" of environmental policies, as suggested by the work of Rumpala (Rumpala, 2000 \& 2003).

In instances where economic actors become involved in RSD, they quickly seize opportunities to implement economic instruments, which for them are more familiar (and conventional) means of policy implementation. In those cases where economic factors dominate RSD, another risk that has been demonstrated in Rumpala's work is that of the "economisation of environmental policy" i.e. that environmental policies are increasingly based on economic principles (Polluter Pays Principle, monetarisation of environmental damages and benefits, etc.) (Rumpala, 1999).

In fact, while economic analyses benefit from relatively advanced methodological input and databases, this is less true for environmental analyses, and even less true for social analyses. Moreover, while environmental dimensions benefit from new methodological tools, in particular global analysis as a measure of the ecological footprint, such methodologies remain relatively weak in assessing the social dimensions of actions, as also shown by practices in other countries.

Bridging the gap between technical and political levels: the indispensable political support or technocratic drift

The linkage between sustainable development policies at technical and political levels is variable and seems to depend largely on the political support for the procedure. If 
elected representatives have initiated or are interested in this linkage, the dynamics are bound to be strong. Bridges will be built between the work carried out at a technical level and the discussions being held at a political level, and the dynamics of each group will support the other. It will then be possible to see a real process of regional appropriation by elected representatives and technicians.

On the other hand, if the elected representatives have no real belief in SD, but allow it to proceed because they have no choice, then there will be no bridge constructed between the technical and political levels. There is then a real risk that the procedure will fall into technocratic isolation. Basically, there can be no solid assessment procedure for sustainable development without political support.

With regard to the question of appropriating sustainable development at the levels of elected representatives and departments, the ideal objective is that this appropriation be collective and shared. However, the underlying political and institutional stakes mean that the process gravitates towards competitive appropriation.

Experience indicates that for the dynamics of sustainable development or SD evaluation processes to take root, policy-makers must be environmentally sympathetic. In spite of its success and the fact that it has been widely adopted into political language, sustainable development still seems to lack a real political presence. Its current diffuse quality makes it difficult for elected representatives to engage with, and it only rarely achieves a political profile that is convincing enough to ensure effective promotion.

The delicate position of environmental actors: between exclusive appropriation and loss of their field of action

Local or regional measures that incorporate sustainable development, notably through evaluation, require a minimum amount of debating space for their existence and to 
ensure joint appropriation. In order to function and cohere between the different procedures, actors are required to bridge the divide. In this context, the role of environmental actors appears crucial, based on their awareness and involvement in a large number of questions closely linked to sustainable development. However, their position is delicate on account of two pitfalls: actors responsible for the environment must ensure the promotion of sustainable development without monopolising it or reducing it to its purely environmental dimension; and they must avoid dissolving the environment into sustainable development, in other words prevent precisely formulated environmental concerns from being diluted into less precise concerns related to sustainability.

\section{Conclusion}

\section{General trade-offs}

Based on the examples of contract-based planning, the introduction of sustainable development leads mainly to strengthening environmental policies, without significantly changing the approach of other sectoral policies. As a result, regional environmental issues must be shared out between all the actors, and concerns about the environment introduced to other areas of action in social affairs (e.g. education about the environment) or the economy (green jobs, development of eco-industries and pollution treatment technologies, increase of eco-management, use of renewable energy in firms, etc.).

On the other hand, actions that combine social affairs and the economy (such as integrated economy or decentralised cooperation) are few in number and only receive marginal support. Moreover, the large number of social actions for reducing 
unemployment, poverty, exclusion etc. carried out at national, regional and local levels are not as explicitly linked to sustainable development as the environment issue ${ }^{16}$. Clearly, regional sustainable development in France continues to be strongly influenced by its relationship with the environment.

Adopting sustainable development as a new objective of public action contributes to the transformation of the way public policies are designed. It creates opportunities to implement cross-sectorality and opens up possibilities for debate within regional institutions. However, it does not appear to be in a position to modify the macroobjectives of development or the timeframe in which decisions are taken. Lastly, the effectiveness of the regional dynamics of SD relies not upon more-or-less sophisticated technical machinery, but instead it requires a real appropriation by regional politicians.

\section{Bibliography}

BELLAREDJ F. \& BAILLON J.-N. (2003), «Evaluation de la démarche de territorialisation des actions emplois-formation du Service Public de l'Emploi en Aquitaine", communication aux 5èmes journées de la SFE, Limoges, Octobre 2003, 8 p.

BERTRAND F. (2004), Planification et développement durable: vers de nouvelles pratiques d'aménagement régional ? L'exemple de deux Régions françaises, Nord-pas-de-Calais et Midi-Pyrénées, Thèse pour l'obtention du grade de docteur en Aménagement de l'Espace et Urbanisme, Université de Tours, $562 \mathrm{p} .+$ annexes

BERTRAND F., LARRUE C. \& HELAND L. (2003), National report on regional sustainable development in France. A national analysis illustrated by two regional studies (Midi-Pyrénées and NordPas-de-Calais), contribution to the european thematic network REGIONET, Research center VilleSociété-Territoire, University of Tours, december 2003, 45 p. [www.iccr-international.org/regionet]

BRIDGE G. \& McMANUS P. (2000), «Sticks and Stones: Environmental Narratives and Regulation in the Forestry and Mining Sectors », pp.10-47 in Antipode 32:1, Blackwell Publishers, Oxford

CANS C. (2003), «Le développement durable en droit interne : apparence du droit et droit des apparences », AJDA (Actualité Juridique du Droit Administratif), n5/2003, 10/02/2003, pp. 210-218

\footnotetext{
${ }^{16}$ These actions are unrelated to the issues of SD and seem to develop independently, with no claim to form part of the SD framework. This was the initial remark of two assessors in a presentation of their work to the French Evaluation Society (Bellaredj F. \& Baillon J-N, 2003).
} 
DUPOIRIER E. (1999), «Enjeux environnementaux et aménagements du territoire », enquête de l'OIP (Observatoire Interrégional du Politique), pp.6-16 in Cahier du PROSES n²1, Sciences Po-MATE, Paris, $28 \mathrm{p}$.

HOLEC, N. (2001), Dynamiques régionales de développement durable, Ministère de l'Aménagement du Territoire et de l'Environnement \& Association 4D, septembre 2001, 81 p.

GEORGESCU-ROEGEN N. (1971), The Entropy Law and the Economic Process, Harvard Univesity Press, Cambridge

LABORIE J.P., LANGUMIER J-F. \& DE ROO P. (1985), La politique française d'aménagement du territoire de 1950 à 1985, Ministère de la Coopération et de l'Aménagement - La Documentation Française, Paris, 176 p. + Annexes

LAGUGIE J., DELFAUD P. \& LACOUR C. (Dir.) (1985), Espace régional et aménagement du territoire, Dalloz, Paris, $2^{\text {ème }}$ édition, 987 p. ( $1^{\text {ère }}$ éd. 1979)

LATOUCHE S. (1991), La planète des naufragés. Essai sur l'après-développement, éd. La Découverte, Paris

LATOUCHE S. (1999), « La double imposture du développement durable », in GEOGRAPHICA HELVETICA (1999), De l'aspiration au progrès à la notion de développement durable, Revue Suisse de Géographie, N²-1999, p.71-113

PARTANT F. (1982), La fin du développement. Naissance d'une alternative ?, Maspero, Paris, $2^{\text {ème éd. }}$ 1997, Actes Sud, Paris

RIST G. (1996), Le développement, histoire d'une croyance occidentale, Presses de la Fondation

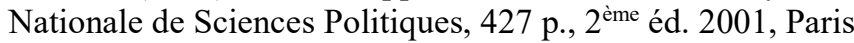

RUMPALA Y. (1999), Questions écologiques, réponses économiques. Les changements dans la régulation publique des problèmes d'environnement au tournant des années 1980 et 1990, une analyse intersectorielle, Thèse en Science Politique, sous la direction de Pierre LASCOUMES, Institut d'Etudes Politiques de Paris

RUMPALA Y. (2000), «Voies et ambiguïtés du repositionnement de la régulation publique face au développement durable. Esquisses d'analyses à partir du cas français », intervention du 07/12/2000 au Séminaire Interdisciplinaire sur le Développement Durable, Lille, 22 pp. [www.revue-ddt.org]

RUMPALA Y. (2003), Régulation publique et environnement. Questions écologiques, réponses économiques, L'Harmattan, coll. Logiques Politiques, Paris, 373 p.

THEYS J. (2002), « L'aménagement du territoire face au développement durable: sens et limites d'une intégration », in LARRUE C. (Ed.), Recherche et développement régional durable, actes du troisième symposium européen, MSH Université de Tours pp 27-43.

ZUINDEAU B. (Ed.) (2000), Développement durable \& Territoires, Presses Universitaires du Septentrion, Villeneuve d'Ascq, 289 p. 